\title{
Laboratory Study on Lime and Cement Treated Marine Clay Subgrade Flexible Pavements
}

\author{
Er. D. Venkateswarlu ${ }^{1}$, Dr. M. Anjan Kumar ${ }^{2}$, Dr. G .V . R. Prasada Raju ${ }^{3}$, \\ Dr. D. S. V. Prasad ${ }^{4}$ K. D. V. Prasada Raju ${ }^{5}$, \\ ${ }^{I}$ Research Scholar, Dept.of Civil Engineering, JNTU Kakinada, Andhra Pradesh, India, \\ ${ }^{2}$ Principal, B.V.C.College of Engineering, Rajahmundry, Andhra Pradesh, India, \\ ${ }^{3}$ Professor of Civil Engg., and Registrar JNTU Kakinada, Andhra Pradesh, India \\ ${ }^{4}$ Principal, B.V.C. Engineering College, Odalarevu, Andhra Pradesh, India, \\ ${ }^{5}$ Graduate Student, Dept. of Civil Engineering, JNTU Kakinada, Andhra Pradesh, India,
}

\begin{abstract}
With the increase in population and the reduction of available land, more and more construction of buildings and other civil engineering structures have to be carried out on weak or soft soils. Owing to such soils of poor shear strength and high compressibility, a great diversity of ground improvement techniques such as soil stabilization and reinforcement are employed to improve mechanical behavior of soils, thereby enhancing the reliability of construction. As a good stabilizing agents, lime and cement are extensively applied in soil stabilization of foundation soils or road subgrades. However, lime+cement treated soil can be used for subgrade as an alternative to the traditional "remove and replace" strategies commonly utilized and is found to be satisfactory in the laboratory evaluation. Hence the author has added an optimum content of lime and cement to marine clay and further used the treated marine clay as subgrade over laid by different alternative subbases to study the performance of treated marine clay under cyclic load conditions.
\end{abstract}

Key words: Marine Clay, Lime+Cement, Stabilized fly ash subbase, Flexible Pavement

\section{Introduction}

Now a days it is common practice of stabilizing problematic soils using additives in road foundation construction when the subgrade soil is not capable of carrying the imposed traffic loads and reinforcement is installed between the subbase and subgrade with the aim of reducing the stresses that are transferred to the subgrade from the overlying layers of the pavement. It usually consists of either traditional granular materials such as locally available gravel or recycled materials or chemically stabilized materials. However a stabilized soil does not just contribute the strength of the foundation but also reduces the permeability of the soils and increase the durability against weathering or traffic usage [1]. All these, together with several restrictions imposed to protect the environment, industrial wastes as stabilizing materials, make a better option for the highway engineer. The soft, weak subgrade materials can be made useful by strengthening and stiffening with small additions of chemicals, rather than being excavated and discarded, and at the same time the environmental impact of the work is minimized.

Lime, or $\mathrm{CaO}$, the burned byproduct of lime stone $\left(\mathrm{CaCO}_{3}\right)$, is one of the oldest developed construction materials, and humans had been using it for more than 2,000 years, when the Romans used soil-lime mixtures to construct roads. However, its utility in modern geotechnical engineering applications was limited until 1945, mostly because of lack of proper understanding of the subject [2]. Today, lime stabilization of soils is widely used in several structures such as highways, railways, airports, embankments, foundation base, slope protection, canal linings, and others [3]. This prevalent use of lime is primarily because of its overall economy and ease of construction, coupled with simplicity of this technology that provides an added attraction for engineers. Several research studies highlighted the beneficial effect of lime in improving soil performance.

An important phenomenon reported by many researchers is the ability of lime to change the plasticity of soils. Both the liquid limit and the plastic limit are influenced by lime, which affects the thickness of the diffused hydrous double layer surrounding the clay particles and also the liquid limit of clay was found to decrease with increase in the lime content [4] [5], the plastic limit generally shows an increasing trend [2] [6]. A greater amount of clay results in a higher plasticity and thereby lime-induced increase in the plastic limit [7]. Correspondingly, the plasticity index, the mathematical difference of the liquid limit and the plastic limit that quantifies the plasticity of soils, is generally found to decrease with lime amendment [2] [5], making the soil more friable and therefore more workable. High plastic soils generally contain clay minerals such as montmorilonite, which has large affinity for water. Therefore, such soils undergo large swelling, leading to severe distress and damage to the overlying structures [8]. Through physicochemical modifications, lime can effectively control the swelling of soils [9] [10]. Correspondingly, the swell pressure and, hence, damage and distortion of the superstructure substantially decreased [3]. 
Apart from modifying the plasticity and swelling characteristics, lime can stabilize the soils through cementation, giving rise to visible increases in strength and stiffness [11] [12] [13]. The cementation is primarily attributable to pozzolanic reactions and can significantly improve the long-term performance of the stabilized soils [14] [15]. Several case studies highlighted the application of lime stabilization in improving the performance of problematic soils [16] [8] [3]. Investigation on chemical stabilization [17] [18] revealed that electrolytes like potassium chloride, calcium chloride and ferric chloride may be effectively used in place of conventionally used lime, because of their ready dissolvability in water and supply of adequate cations for ready cation exchange.

However, in some cases, lime is reported to produce adverse effects on the performance of soils. Increase in the liquid limit and plasticity index [19] [20] [11] indicate that lime increased the plasticity of the soils that it treats. This result is suggested from the action of hydroxyl ions modifying the water affinity of the soil particles. Moreover, increase in lime content beyond a certain limit was found to decrease the strength gain [7] [2] [11] [21]. Because lime itself has neither appreciable friction nor cohesion, excess of lime is postulated to reduce its strength. However, lime stabilization is dependent on several factors such as soil type, its mineralogy, lime content and curing period, and also is a complex problem that needs careful reevaluation.

Zhang et al under took an experimental program to study the individual and admixed effects of lime and flyash on the geotechnical characteristics of soil. They observed reduction in free swell and increase in CBR value [25]. Later on it was observed that lime-flyash admixtures reduced the water absorption capacity and compressibility of soils. Phani kumar and Radhey Sharma reported that flyash can be used as an additive in improving the engineering characteristics of soils [22]. They observed the decrease in plasticity and hydraulic conductivity and increase in penetration resistance of blends with increase in fly ash content.

Researchers have practiced different remedial techniques such as chemical stabilizations pre wetting, moisture control and soil replacement with different success levels. Unfortunately the limitations of these techniques questioned their adaptability in all conditions. So work is being done all over, to evolve more effective and practical treatment methods, to alleviate the problems caused to any structures laid on marine clay deposits. Hence the authors aimed at the present investigation to evaluate the performance of Marine Clay when treated with optimum combination of lime and cement under cyclic plate load conditions.

\subsection{Marine Clay}

\section{Materials Used}

The marine clay was collected from Kakinada seaports limited, Kakinada at a depth of $1.4 \mathrm{~m}$. Kakinada seaport is situated on the east coast of India at latitude of $16^{\circ} 56^{\prime}$ north and longitude of $82^{0} 15^{\prime}$. The properties of the marine clay assessed based on relevant I.S. Code provisions are given in Table.1.

Table.1.

\begin{tabular}{|c|c|}
\hline Property & Value \\
\hline Specific Gravity & 2.62 \\
\hline \multicolumn{2}{|l|}{ Grain size Distribution } \\
\hline Sand $(\%)$ & 8 \\
\hline Slit $(\%)$ & 19 \\
\hline Clay $(\%)$ & 73 \\
\hline \multicolumn{2}{|l|}{ Compaction Properties } \\
\hline Maximum Dry Density $\left(\mathrm{kN} / \mathrm{m}^{3}\right)$ & 13.9 \\
\hline $\mathrm{OMC}(\%)$ & 27.4 \\
\hline \multicolumn{2}{|l|}{ Atterberg Limits } \\
\hline Liquid Limit (\%) & 76 \\
\hline Plastic Limit (\%) & 32 \\
\hline Plasticity Index (\%) & 44 \\
\hline Shrinkage Limit (\%) & 14.5 \\
\hline IS Classification & $\mathrm{CH}$ \\
\hline Differential Free Swell (\%) & 38 \\
\hline Un soaked CBR (\%) & 2.24 \\
\hline $\begin{array}{l}\text { Soaked CBR (Compact to MDD at } \\
\text { OMC) }(\%)\end{array}$ & 0.98 \\
\hline \multicolumn{2}{|l|}{ Shear parameters } \\
\hline $\mathrm{C}(\mathrm{Kpa})$ & 62 \\
\hline$\varnothing$ & $0^{0}$ \\
\hline
\end{tabular}

\subsection{Murrum}


The Murrum used as subbase material in this investigation, was collected from Dwarapudi, East Godavari District, Andhra Pradesh, India. The properties of murrum are furnished below in Table.2.

Table.2.

\begin{tabular}{|l|l|l|}
\hline S.No & Property & Value \\
\hline 1 & Specific Gravity & 2.7 \\
\hline 2 & Grain size Distribution & \\
\hline & Gravel (\%) & 61 \\
\hline & Sand (\%) & 28 \\
\hline & Slit \& Clay (\%) & 11 \\
\hline 3 & Compaction Properties & \\
\hline & $\begin{array}{l}\text { Maximum Dry Density } \\
\left(\mathrm{kN} / \mathrm{m}^{3}\right)\end{array}$ & 19.4 \\
\hline & OMC (\%) & 12 \\
\hline 4 & Atterberg Limis & 24 \\
\hline & Liquid Limit (\%) & 20 \\
\hline 5 & Plastic Limit (\%) & 4 \\
\hline 6 & Plasticity Index (\%) & 17.4 \\
\hline & $\begin{array}{l}\text { Soaked CBR (Compacted to } \\
\text { MDD at OMC) (\%) }\end{array}$ & $1.42 \times 10^{-2}$ \\
\hline & Permeability (cm/sec) \\
\hline
\end{tabular}

\subsection{Flyash}

Another subbase material flyash, was collected from Dr. Narla Tata Rao thermal power station, NTTPS, Vijayawada, Andhra Pradesh, India. The properties of flyash are furnished below in Table.3.

Table.3.

\begin{tabular}{|c|l|c|}
\hline Sl.No & \multicolumn{1}{|c|}{ Properties } & Fly ash \\
\hline $\mathbf{1}$ & \multicolumn{1}{|c|}{$\begin{array}{c}\text { Grain size distribution } \\
\text { Gravel (\%) }\end{array}$} & $\mathbf{2 3}$ \\
& \multicolumn{1}{|c|}{$\begin{array}{c}\text { Sand (\%) } \\
\text { Silt size (\%) } \\
\text { Clay Size (\%) }\end{array}$} & $\mathbf{7 1}$ \\
& \multicolumn{1}{|c|}{$\mathbf{0 6}$} \\
\hline 2 & $\begin{array}{l}\text { Atterberg's Limits } \\
\text { Liquid limit (\%) }\end{array}$ & 36 \\
\hline 3 & $\begin{array}{l}\text { Compaction properties } \\
\text { Optimum moisture contents } \\
\end{array}$ & \\
& $\begin{array}{l}\text { Maximum dry density } \\
\left.\text { (kN/m }{ }^{3}\right)\end{array}$ & 20 \\
\hline 4 & Specific Gravity & 11.9 \\
\hline 5 & Free Swell index & 2.12 \\
\hline 6 & Soil Classification & $\ldots$. \\
\hline 7 & Soaked CBR (Compacted to & ML \\
\hline 8 & MDD at OMC) (\%) & 7.8 \\
\hline
\end{tabular}

\subsection{Additives}

In the present study commercial grade lime mainly consisting of $61.05 \% \mathrm{CaO}$ and $7.9 \%$ Silica and ordinary Portland cement (OPC) were used in the study.

\subsection{Aggregates}

Road aggregates of size between $20-40 \mathrm{~mm}$, confirming WBM-III standards was used for the preparation of base course in the investigation of the modal flexible pavements.

\section{Construction Of Model Flexible Pavement And Expermental Setup And Procedure}

In the present investigation ten model flexible pavements were prepared in the laboratory by using $60 \mathrm{~cm}$ diameter mild steel tank with different alternatives given in table 4 . Untreated marine clay and treated marine clay were used as subgrade soils for all the tests. Out of the ten model flexible pavements five with Untreated marine clay subgrade and other five with treated marine clay subgrade were considered in this study. Above all the subbases WBM-III base course was laid uniformly. The details of construction procedures followed in the construction of model flexible pavements in the test tank are given below.

Table.4. 


\begin{tabular}{|c|l|c|}
\hline Subgrade & \multicolumn{1}{|c|}{ Subbase } & \multicolumn{1}{c|}{$\begin{array}{c}\text { Base } \\
\text { course }\end{array}$} \\
\hline Marine clay & Lime + Cement stabilized Flyash & WBM-III \\
\hline Marine Clay & Cement stabilized Flyash & WBM-III \\
\hline Marine Clay & Lime stabilized Flyash & WBM-III \\
\hline Marine Clay & Murrum & WBM-III \\
\hline Marine Clay & Flyash & WBM-III \\
\hline $\begin{array}{c}\text { Treated Marine Clay } \\
(3 \% \text { L+1\%C) }\end{array}$ & Lime + Cement stabilized Flyash & WBM-III \\
\hline Treated Marine Clay & Cement stabilized Flyash & WBM-III \\
\hline Treated Marine Clay & Lime stabilized Flyash & WBM-III \\
\hline Treated Marine Clay & Murrum & WBM-III \\
\hline Treated Marine Clay & Flyash & WBM-III \\
\hline
\end{tabular}

\subsection{Preparation of unTreated and treated marine clay subgrade}

Sand bed of $1.0 \mathrm{~cm}$ thick was placed before laying the subgrade soil in the tank. The marine clay brought from Kakinada seaports limited, Kakinada was allowed to dry and then pulverized and sieved through $4.75 \mathrm{~mm}$ sieve. Then it was compacted to $4.0 \mathrm{~cm}$ thickness in 5 layers to a total thickness of $20 \mathrm{~cm}$ to its optimum moisture content and maximum dry density in the selected mild steel test tank. Vertical drains were provided by means of 6 perforated vertical PVC pipes of $1.27 \mathrm{~cm}$ diameter from bottom of the subgrade to top of the base course for attaining full saturation. In the similar procedure explained above the treated marine clay subgrade was prepared by mixing the virgin marine clay with $3 \%$ lime and $1 \%$ cement (optimum contents obtained from the laboratory investigation). Vertical drains were provided as explained above. A typical model test tank can be seen in plate 1 .

\subsection{Preparation of subbase}

On the prepared untreated and treated marine clay subgrades, murrum mixed with water at OMC was laid in two layers each of $2.5 \mathrm{~cm}$ compacted thickness to a total thickness of $5.0 \mathrm{~cm}$. The subbase layer was compacted at the corresponding MDD and OMC.

On the prepared subgrade, flyash subbase was prepared and compacted corresponding to maximum dry density at optimum water content of flyash. For the other subbase, flyash was treated with $8 \%$ lime (obtained from laboratory CBR test results) was added and compacted corresponding to maximum dry density at optimum moisture content of flyash. For cement stabilized flyash subbase, $2 \%$ cement was mixed with flyash (obtained from laboratory CBR test results) was used as a stabilizing agent. The lime - cement stabilized flyash subbase was prepared similar to cement stabilized flyash subbase except in place of cement, $2 \%$ lime $+0.5 \%$ cement (obtained from laboratory CBR test results) were added to flyash and compacted corresponding to maximum dry density at optimum moisture content of flyash.

\subsection{Base course}

On the prepared subbase two layers of WBM-III each of $2.5 \mathrm{~cm}$ compacted thickness, were laid to a total thickness of $5.0 \mathrm{~cm}$.

\section{4 . Experimental setup and Procedure}

All the tests were conducted in full saturation condition, the soil was allowed to absorb water by providing a thin sand layer $(10 \mathrm{~mm}$ thick) at the bottom and also through the 6 vertical PVC pipes of $1.27 \mathrm{~cm}$ diameter (1/2 inch). Each pipe is of $65 \mathrm{~cm}$ long (which is more than the height of the tank) and all the pipes are made with perforations for the bottom $20 \mathrm{~cm}$ in all the pipes, inserted circularly in the tank. After laying all the layers (i.e., subgrade (20 cm thick), subbase (5cm thick) and base course WBM-III (5cm thick)) in the tank all the pipes are filled with water to a certain level and the water is poured on the top of the basecourse and tank is left for saturation. The water level in the pipes and at the top of the base course is continuously monitored. The water level is maintained constant in all the pipes and at the top of the base course by pouring the water in the soil is saturated. After the water level becomes constant without further addition of water both in pipes and at the top of the base course it indicates that the soil is fully saturated. Then all the pipes are taken out from the tank by rotating slowly in the counter clockwise direction and the cavities are filled, compacted with the materials corresponding to each layer. The typical view of the tank is shown in Plate.1. 


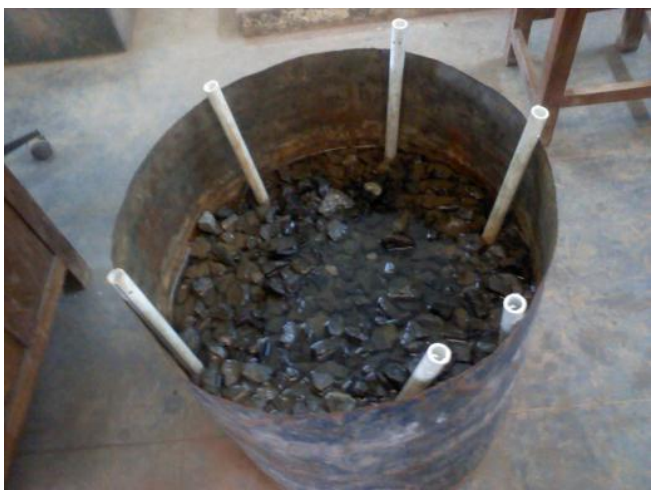

Plate 1 saturation of model tank

The laboratory plate load tests were carried out on flexible pavements systems in a circular steel tank of diameter $60 \mathrm{~cm}$ as shown in Fig. 1 the loading was done through a circular metal Plate of $10 \mathrm{~cm}$ diameter laid on the model flexible pavement system. The steel tank was placed on the pedestal of the compression testing machine. A $50 \mathrm{kN}$ capacity proving ring connected to the loading frame and the extension rod welded to the circular plate was brought in contact with proving ring. Two dial gauges of least count $0.01 \mathrm{~mm}$ were placed on the metal flats welded to the vertical rod to measure the vertical displacements of the loading plate. The load was applied, cyclically, until there was insignificant increase in the settlement of the plate between successive cycles. The testing was further continued till the occurrences of failure to record the ultimate loads. The entire setup was shown in the Fig.1.

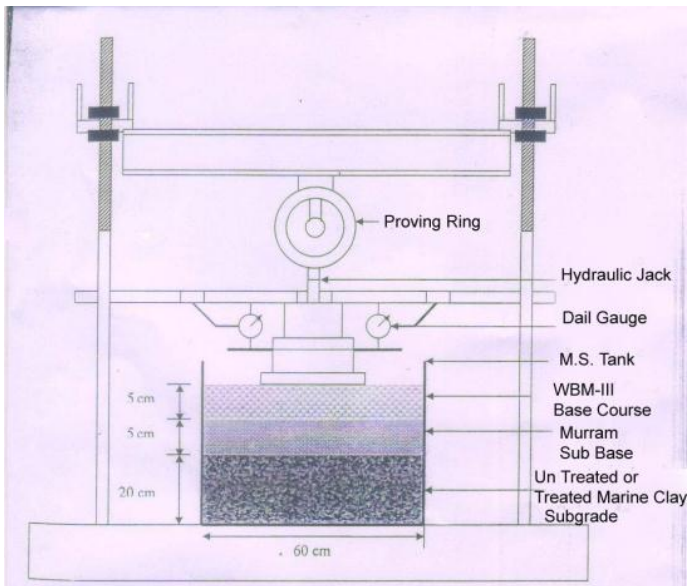

Fig. 1 Laboratory Experimental Setup for Conduct of Cyclic Load Test.

\section{Results And Discussion}

Cyclic plate load tests were conducted on Untreated Marine Clay and Treated Marine Clay as subgrade with different alternative subbases and WBM-III as base course in the model flexible pavement under pressures, viz $500 \mathrm{kPa}, 560 \mathrm{kPa}, 630 \mathrm{kPa}, 700 \mathrm{kPa}, 1000 \mathrm{kPa}$ and $1200 \mathrm{kPa}$. The tests were conducted until the failure of Untreated Marine clay and Treated Marine Clay model flexible pavements at FSC (Full Saturation Condition) and the results were given in the Fig.2 to Fig.5 and table 5.

Fig. 2 \& 4 shows to pressure Vs total deformation curves for different alternatives of flexible pavement systems laid on Untreated and Treated Marine Clay subgrades respectively. From the above figures we can clearly see that the load carrying capacity was increased and the deformations were reduced marginally. For a particular load the observed deformation decreased for treated subgrade. This shows that the improvement in Marine Clay properties improved the performance of the pavement system laid on it irrespective of the subbase alternative. It is also evident from the figs 3 and 5 the elastic deformation had also shown the similar trend as of the total deformation.

From the table 5 , it is sure that the ultimate load carrying capacity improved by about $70 \%$ were almost the same total deformation and also for the same alternative subbase, when the Marine clay subgrade was treated with $3 \%$ Lime and $1 \%$ Cement.

From the above discussions it can be inferred that, by treating weak Marine clay subgrade, the pavement performance was enhanced and there by evolved and better alternate pavement system particularly if these week deposits are encountered in the road alignment. Hence the authors effectively initiated the research 
in improving weak marine deposits to cater the pavement requirements and successfully arrived with a suitable solution.

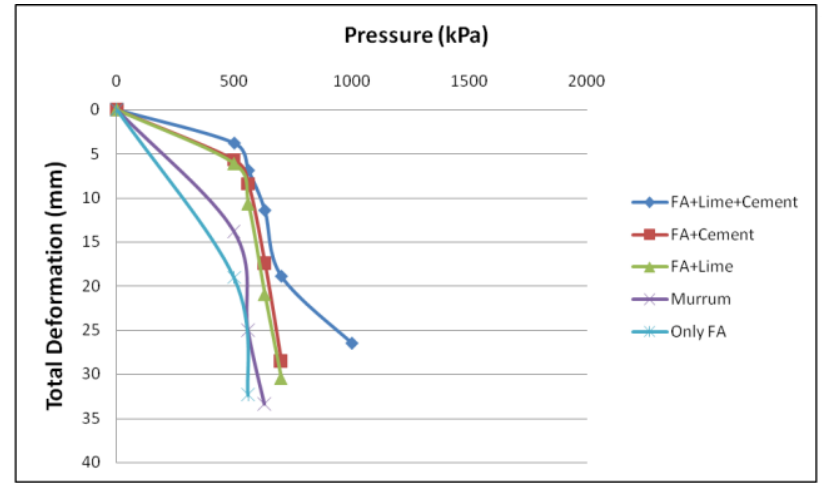

Fig.2 Pressure - Total Deformation Curves for Different alternatives of flexible pavements laid on Marine Clay subgrade at FSC

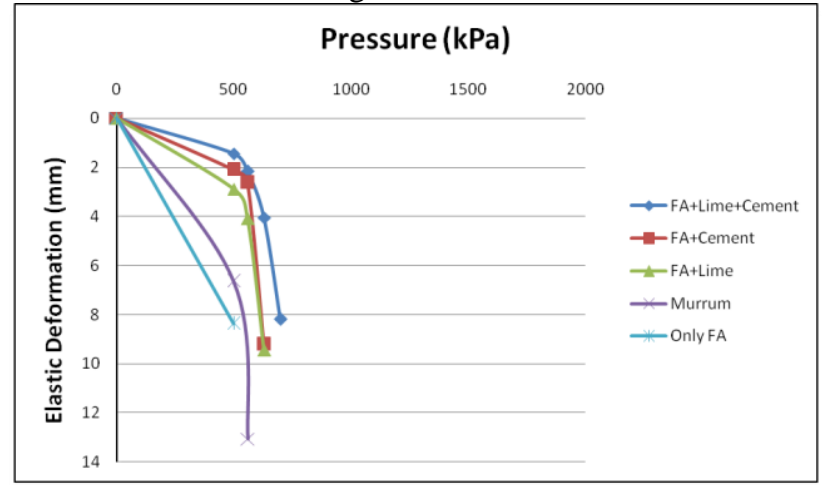

Fig.3 Pressure - Elastic Deformation Curves for Different alternatives of flexible pavements laid on Marine Clay sub grade at FSC

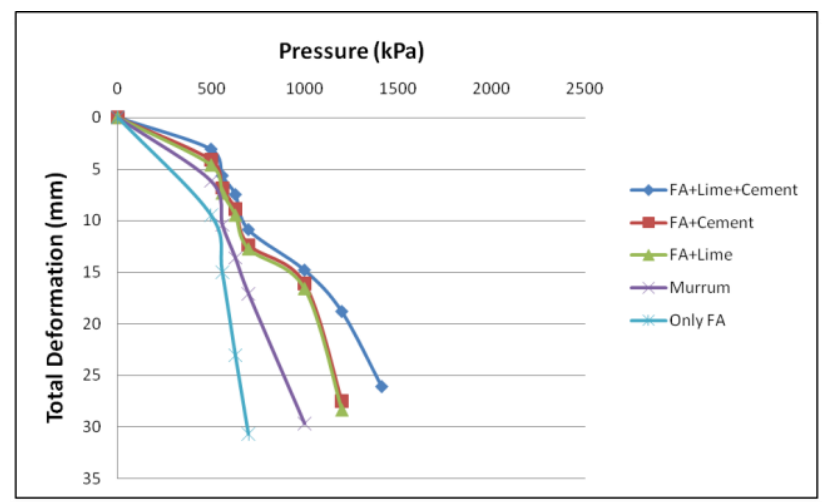

Fig.4 Pressure - Total Deformation Curves for Different alternatives of flexible pavements laid on Treated Marine Clay sub grade at FSC

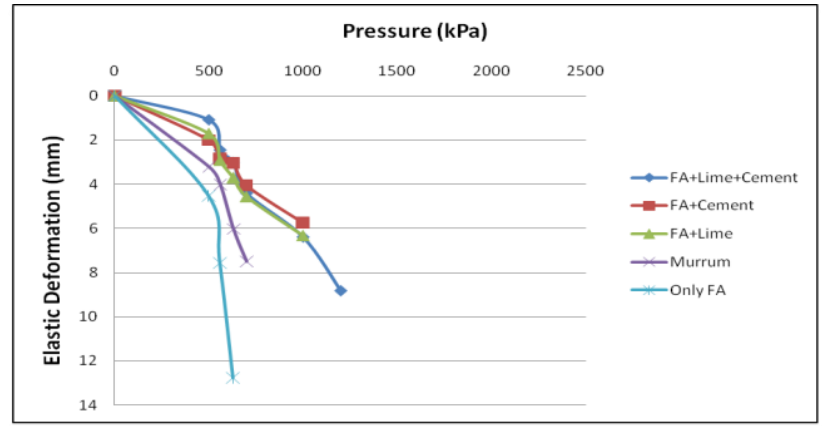

Fig.5 Pressure - Elastic Deformation Curves for Different alternatives of flexible pavements laid on Treated Marine Clay sub grade at FSC 
Table -5 . Laboratory cyclic plate load test results of Un Treated and Treated Marine Clay flexible pavements at FSC.

Table. 5.

\begin{tabular}{|c|l|l|c|c|c|}
\hline $\begin{array}{c}\text { Sl. } \\
\text { No }\end{array}$ & Type of Subgrade & Type of Subbase & $\begin{array}{c}\text { Type of } \\
\text { base } \\
\text { course }\end{array}$ & $\begin{array}{c}\text { Ultimate } \\
\text { load } \\
\text { KPa }\end{array}$ & $\begin{array}{c}\text { Correspondi } \\
\text { ng } \\
\text { deformation } \\
\text { in (mm) at } \\
\text { FSC }\end{array}$ \\
\hline 1 & Marine clay & $\begin{array}{l}\text { Lime-Cement } \\
\text { stabilized Flyash }\end{array}$ & WBM-III & 700 & 18.89 \\
\hline 2 & Marine Clay & $\begin{array}{l}\text { Cement stabilized } \\
\text { Flyash }\end{array}$ & WBM-III & 630 & 17.4 \\
\hline 3 & Marine Clay & Lime stabilized Flyash & WBM-III & 630 & 20.95 \\
\hline 4 & Marine Clay & Murrum & WBM-III & 560 & 25.05 \\
\hline 5 & Marine Clay & Flyash & WBM-III & 500 & 19.04 \\
\hline 6 & $\begin{array}{l}\text { Treated Marine Clay } \\
(3 \% \text { L }+1 \% \text { C) }\end{array}$ & $\begin{array}{l}\text { Lime -Cement } \\
\text { stabilized Flyash }\end{array}$ & WBM-III & 1200 & 18.83 \\
\hline 7 & Treated Marine Clay & $\begin{array}{l}\text { Cement stabilized } \\
\text { Flyash }\end{array}$ & WBM-III & 1000 & 16.08 \\
\hline 8 & Treated Marine Clay & Lime stabilized Flyash & WBM-III & 1000 & 16.59 \\
\hline 9 & Treated Marine Clay & Murrum & WBM-III & 700 & 17.08 \\
\hline 10 & Treated Marine Clay & Flyash & WBM-III & 630 & 23.06 \\
\hline
\end{tabular}

\section{Conclusions}

The following conclusions are drawn based on the results of the laboratory testing.

1. For first alternative it was noticed that from the laboratory investigations of the cyclic plate load test results that, the ultimate carrying capacity of the Treated Marine Clay model flexible pavement has increased from $700 \mathrm{KPa}$ to $1200 \mathrm{KPa}$.

2. For second alternative it was noticed that from the laboratory investigations of the cyclic plate load test results that, the ultimate carrying capacity of the Treated Marine Clay model flexible pavement was increased from $630 \mathrm{KPa}$ to $1000 \mathrm{KPa}$.

3. For third alternative it was noticed that from the laboratory investigations of the cyclic plate load test results that, the ultimate carrying capacity of the Treated Marine Clay model flexible pavement has been increased from $630 \mathrm{KPa}$ to $1000 \mathrm{KPa}$.

4. For fourth alternative it was noticed that from the laboratory investigations of the cyclic plate load test results that, the ultimate carrying capacity of the Treated Marine Clay model flexible pavement increased from $560 \mathrm{KPa}$ to $700 \mathrm{KPa}$.

5. For fifth alternative it was noticed that from the laboratory investigations of the cyclic plate load test results that, the ultimate carrying capacity of the Treated Marine Clay model flexible pavement increased from 500 $\mathrm{KPa}$ to $630 \mathrm{KPa}$.

6. The final conclusion of the present study is that there is an improvement in the ultimate load carrying capacity of the Treated Marine Clay subgrade for all the alternatives of subbase.

\section{References}

[1]. Sherwood, P.T. (1993). "Soil stabilization with cement and lime." State of the art literature review, HMSO, London.

[2]. Herrin, M., and Mitchell, H. (1961) "Lime-soil mixtures.” Bulletin No. 304, Highway Research Board, Washington, DC, 99-138.

[3]. Wilkinson, A., Haque, A., Kodikara, J., Adamson, J., and Christie, D (2010). "Improvement of problematic soils by lime slurry pressure injection : case study.” J. Geotech. Geoenviron. Eng., 136(10), 1459-1468.

[4]. Wang, J.W.H., Mateos, M., and Davidson, D.T. (1963). "Comparative effects of hydraulic, calcitic and dolomitic limes and cement in soil stabilization." Highway Research Record Bulletin No.59, National Research Council, Washington, DC, $42-54$.

[5]. Bell, F.G. (1988) "Stabilization and treatment of clay soils with lime, part I - Basic principles." Ground Eng., 21 (1), 10-15.

[6]. Barker, J.E., Rogers, C.D.F., and Boardman, D. I (2006). "Physiochemical changes in clay caused by ion migration from lime piles." J. mater, Civ. Eng., 18 (2), 182-189.

[7]. Hilt, G. H., and Davidson, D. T. (1960). "Lime fixation on clayey soils" Bulletin No. 262, Highway Research Board, Washington, DC, 20-32.

[8]. Petry, T.M., and Little, D.N. (2002). "Review of stabilization of clays and expansive soils in pavements and lightly loaded structures - history, practice and future.” J. mater. Civ. Eng., 14 (6), 447-460.

[9]. Mateos, M. (1964). "Soil-lime research at lowa State Univ.." J. Soil Mech. and Found, Div., 90 (2), $127-153$.

[10]. Bhasin, N.K., Dhawan, P.K., and Mehta, H.S. (1978). "Lime requirement in soil stabilization" Bulletin No.7, Highway Research Board, Washington, DC, 15-26.

[11]. Bell, F.G. (1996). "Lime stabilization of clay minerals and soils". Eng. Geol., 42(4), 223-237.

[12]. Rajasekharan, G., and Rao, S. N. (2000). "Strength characteristics of Lime-Treated Marine Clay". Proc. Inst. Civ. Eng. Ground Improv.. 4 (3) , 127- 136.

[13]. Consoli, N.C., Lopes, L.S. Jr. Prietto, P.D.M., Festugato, L., and Cruz, R.C. (2011). "Variables controlling stiffness and strength of lime stabilized soils". J. Geotech. Geoenviron. Eng., 137 (6). 628-632.

[14]. Rogers C.D.F., Boardman D.I. and Papadimitriou G. (2006). "Stress Path Testing of Realistically Cured Lime and Lime/Cement Stabilized Clay.” J. Mater, Civ. Eng., 18(2), 259-266. 
[15]. Khattab, S. A. A., Al- Mulkhtar, M., and Fleureau, J. M. (2007). "Long-term stability characteristics of a lime-treated plastic soil". J. Mater. Civ. Eng., 19 (4), 358-366.

[16]. Joshi, R. C., Natt, G.S., and Write. P. J. (1981). "Soils improvement by lime-flyash slurry injection.” Proc. $10^{\text {th }}$ Int. Conf. on Soil Mechanics and Foundation Engineering, AA Balkema, Stockholm, Rotterdam, 3. 707-712.

[17]. Petru, T.M. and Armstrong, J.C., "Stabilisation of Expansive Clay Soils", Transport Research Record No. 1219, TRB, Washington, D.C. pp.103-112, 1989.

[18]. Prasada Raju G.V.R. (2001). "Evaluation of Flexible pavements performance with reinforcement and chemical stabilization of Expansive soil subgrade," a Ph.D. thesis, Kakathiya University, Warangal, (A.P.INDIA).

[19]. Clare, K.E., and Cruchley, A.E. (1957). "Laboratory experiments in the stabilization of clays with hydrated lime." Geotechnique, 7(2). 97-111.

[20]. Prakash, K., Sridharan, A., and Rao, S.M. (1989). "Lime addition and curing effects on the index and compaction characteristics of a montmorillonitic soil". Geotechnical Eng., AIT, 20(1), 39-47.

[21]. Kumar, A., Walia, B.S., and Abjaj, A. (2007). "Influence of fly ash, lime, and polyester fibers on compaction and strength properties of expansive soil". J. Mater, Civ. Eng., 19(3), 242-248.

[22]. Phani Kumar, B. and Sharma, R. (2004). "Effect of Fly Ash on Engineering Properties of Expansive Soils." J. Geotech. Geoenviron. Eng., 130(7), 764-767.

[23]. Dr. D. Koteswara Rao, Venkatesh Ganja and P.R.T. Pranav "International Journal of Modern Engineering Research (IJMER) Vol.2, Issue.5, Sep.-Oct 2012 pp-4465-4469.

[24]. Sujit Kumar Dash, Ph.D., and Monowar Hussain, Ph.D., "Lime Stabilization of Soils : Reappraisal" Journal of materials in civil engineering $\odot$ ASCE/ June 2012/707.

[25]. Zhang Ji-ru and CAO Xing, "Stabilization of expansive soil by lime and fly ash" Journal of Wuhan University of Technology Mater. Sci. Ed. Vol.17, No.4, Dec. 2002. 